\title{
Sensitive and highly specific quantitative real-time PCR and ELISA for recording a potential transfer of novel DNA and Cry1 Ab protein from feed into bovine milk
}

\author{
Patrick Guertler • Vijay Paul • Christiane Albrecht • \\ Heinrich H. D. Meyer
}

Received: 4 November 2008 /Revised: 9 January 2009 / Accepted: 13 January 2009 /Published online: 19 February 2009

(C) Springer-Verlag 2009

\begin{abstract}
To address food safety concerns of the public regarding the potential transfer of recombinant DNA (crylAb) and protein $(\mathrm{Cry} 1 \mathrm{Ab})$ into the milk of cows fed genetically modified maize (MON810), a highly specific and sensitive quantitative real-time PCR (qPCR) and an ELISA were developed for monitoring suspicious presence of novel DNA and Cry $1 \mathrm{Ab}$ protein in bovine milk. The developed assays were validated according to the assay validation criteria specified in the European Commission Decision 2002/657/ EC. The detection limit and detection capability of the qPCR and ELISA were 100 copies of $c r y l A b \mu \mathrm{L}^{-1}$ milk and $0.4 \mathrm{ng}$ $\mathrm{mL}^{-1} \mathrm{Cry} 1 \mathrm{Ab}$, respectively. Recovery rates of $84.9 \%$ (DNA) and $97 \%$ (protein) and low $(<15 \%)$ imprecision revealed the reliable and accurate estimations. A specific qPCR amplification and use of a specific antibody in ELISA ascertained the high specificity of the assays. Using these assays for 90 milk samples collected from cows fed either transgenic $(n=8)$ or non-transgenic $(n=7)$ rations for 6 months, neither crylAb nor Cry1 Ab protein were detected in any analyzed sample at the assay detection limits.
\end{abstract}

Keywords Bovine milk · ELISA · MON810 •

Quantitative real-time PCR · Validation

Patrick Guertler and Vijay Paul have contributed equally to this study.

P. Guertler $(\bowtie) \cdot$ V. Paul $•$ C. Albrecht $\cdot$ H. H. D. Meyer

Physiology Weihenstephan, Technische Universität München,

Weihenstephaner Berg 3,

85350 Freising, Germany

e-mail: patrick.guertler@wzw.tum.de

Present address:

C. Albrecht

Institute of Biochemistry and Molecular Medicine,

University of Bern,

Buehlstr. 12,

3012 Bern, Switzerland

\section{Introduction}

Genetically modified (GM) maize (Bt-maize; event MON810) is one of the most important new generation transgenic insectresistant hybrid plant that has been genetically altered by insertion of the $c r y 1 A b$ gene from a naturally occurring soil bacterium Bacillus thuringiensis (Bt), encoding Cry $1 \mathrm{Ab}$ protein [1] to gain resistance against its major insect pest, the European Corn Borer (Ostrinia nubilalis). Since the past 12 years, after the first commercialized release and approval of GM crops in 1996, the global cultivation area of Bt-maize has increased along with other major biotech crops (soybean, cotton, and canola) reaching a total of 114.3 million ha in 2007 [2]. As a result, there is an increase in the availability of Bt-maize for human and livestock consumption. Despite this consecutive increase in global adoption of GM crops, there is an ongoing debate and increasing public concern about potential effects and the fate of recombinant DNA and protein in the food derived from animals fed GM crops.

Therefore, as a food safety authenticity measure, several countries worldwide including the European Union (EU) have implemented mandatory labeling for foods derived from the GM plants. In the EU, a tolerance limit of $0.9 \%$ has been set before mandatory GMO labeling in food/or feed ingredients [3]. Consequently, for GMO detection, identification, tracing and quantification, the analytical methodologies focused on two targets: the transgenic DNA or the novel protein expressed in a genetically modified organism. The most accepted techniques for accurate and specific detection of recombinant DNA and protein are the polymerase chain reaction (PCR) and the enzyme linked immunosorbent assay (ELISA). Various analytical methods [4-8] have been developed and routinely used for the monitoring of GMOs in raw materials and processed foods. 
However, the possible transfer of transgenic DNA and protein to animal-derived products like milk, intended for human consumption, needs to be fully addressed. Previously described analytical methods for the detection of $c r y 1 A b$ DNA in milk [9-12] either amplified fragments of transgenic DNA using event specific gene primers in qualitative PCR or quantified transgenic DNA in quantitative real-time PCR (qPCR) based on total plant DNA mass calibrations. Therefore, the quantification of recombinant DNA fragments using qPCR based on the copy number of inserted transgene calibration could give better details of even minute amounts of the transgenic material in the samples. Furthermore, these methods need proper validation before application in complex matrices like milk.

On the other hand, so far only one commercially available enzyme immunoassay kit [13] has been used for monitoring the novel CrylAb protein in milk. However, the used commercial kit designed for the GMO detection in plant materials has not been adequately validated. According to EU Regulation (EC) 882/2004, analytical methods used for food and feed control purposes must be validated before their use in control laboratories. Though, a validated quantitative method for the detection of event MON810 has been published by the Community Reference Laboratory for GM Food and Feed (http://gmo-crl.jrc.ec.europa. eu/summaries/Mon810_validation_report.pdf). However, to the best of our knowledge, there is no validated method for the quantification of recombinant DNA and protein from event MON810 by means of quantitative real-time PCR and ELISA in bovine milk.

Therefore, the aim of the present study was to optimize and validate a sensitive and specific extraction and detection method for recombinant DNA and the CrylAb protein in bovine milk samples. The methods were further used for the monitoring of presence or absence of the suspected recombinant DNA and CrylAb protein in the milk of multiparous cows fed GM maize or non-GM maize supplemented rations.

\section{Materials and methods}

Milk samples and feeding experiment

Milk samples from cows fed on non-GM diet were taken from a bulk milk storage tank and used for assay (quantitative real-time PCR and ELISA) optimization and validation. In addition, 54 milk samples from different cows reared at three farms maintaining three different breeds (Veitshof: 12 Brown Swiss cows, Grub: seven Bavarian Fleckvieh cows and, Hirschau: 35 Red Holstein cows) were collected in sterile Falcon tubes $(50 \mathrm{~mL})$ for ELISA validation.

To investigate the possible transfer and existence of novel DNA and Cry1 Ab protein in the milk of cows fed on a ration supplemented with the GM maize (MON810), a 6-month feeding trial was conducted on 15 multiparous (2nd lactation) lactating Bavarian Fleckvieh cows. All cows were housed at the Bavarian State Research Center (LfL, Grub, Germany) and separated into a target group $(n=8)$ fed on a ration containing GM maize (MON810) and a control group $(n=7)$ fed conventional maize. Daily diet of cows contained a partial mixed ration. The feed composition is shown in Table 1. According to the milk yield, further concentrates $(40.4 \%$ maize kernels, $34.4 \%$ rapeseed meal, $19.9 \%$ molasses dried beet pulp, 3.2\% mineral mixture and $2.4 \%$ urea) were offered above $22 \mathrm{~kg}$ milk yield per day. Milk samples were taken monthly during the morning milking and stored at $-20{ }^{\circ} \mathrm{C}$ until analyzed.

For Cry $1 \mathrm{Ab}$ protein quantification and assay validation in ELISA, the skim milk was prepared by centrifugation of whole milk (fresh whole milk, pooled tank milk, and thawed frozen milk samples) at $3,000 \times g$ for $15 \mathrm{~min}$ at $4{ }^{\circ} \mathrm{C}$ in inversely (lid down) placed centrifuge tubes. After centrifugation, the skim milk was collected in clean vials by decantation and further used in the ELISA.

DNA analysis

To optimize and validate a sensitive DNA extraction method from milk, whole milk samples were spiked with the genomic DNA isolated from transgenic maize (MON810) containing different copy numbers of $c r y l A b$. Therefore, genomic DNA was first isolated from MON810 using an optimized CTAB-based protocol published by the Federal Office of Public Health (FOPH, Berne) [14].

\section{Genomic DNA extraction from maize}

Three hundred milligrams of grounded GM maize (MON810) kernels and $800 \mu \mathrm{L}$ of a CTAB-extraction buffer

Table 1 Feed composition of the daily animal diet

${ }^{\text {a }}$ Ingredients contained $100 \%$ MON810 in GM ration and conventional maize in non-GM ration

\begin{tabular}{ll}
\hline Component & Ratio (DM) \\
\hline Maize silage $^{\mathrm{a}}$ & $41.9 \%$ \\
Maize cobs $^{\mathrm{a}}$ & $21.2 \%$ \\
Grass silage & $11.0 \%$ \\
Straw & $5.9 \%$ \\
Molasses & $1.4 \%$ \\
Concentrates & $18.6 \%$ \\
Rapeseed meal & $51.1 \%$ \\
Maize kernels & $41.2 \%$ \\
Mineral mixture & $5.3 \%$ \\
Urea & $2.4 \%$ \\
\hline
\end{tabular}


were added to FastPrep-tubes containing 300-mg beads (Lysing Matrix D, MP Biomedicals, Germany). The mixture was homogenized (two times for $30 \mathrm{~s}$ at a speed of $5.5 \mathrm{~m} \mathrm{~s}^{-1}$ ) using the FastPrep FP120 (MP Biomedicals, Germany) and cooled on ice between the runs, followed by Proteinase K (Roth, Germany) digestion. Samples were incubated overnight at $60{ }^{\circ} \mathrm{C}$ and subsequently centrifuged (at $16,000 \times g$ for 15 min at $4{ }^{\circ} \mathrm{C}$ ). The supernatant was transferred into a new tube, RNAse A (Roth, Germany) was added and the mixture was incubated for $15 \mathrm{~min}$ at $60{ }^{\circ} \mathrm{C}$. After centrifugation ( $1 \mathrm{~min}$ at $16,000 \times g$ and room temperature), the clear supernatant was transferred to a new tube and $600 \mu \mathrm{L}$ chloroform was added. The tubes were mixed immediately and centrifuged for $10 \mathrm{~min}$ at $16,000 \times g$ and $4{ }^{\circ} \mathrm{C}$. The upper watery phase, containing the DNA, was collected and added to a tube prefilled with $500 \mu \mathrm{L}$ 2-propanol $(80 \%)$. Glycogen (Sigma, Germany) was added into the lid and the tubes were inverted four times, followed by an incubation step of $60 \mathrm{~min}$ at room temperature (RT). The DNA was pelleted by centrifugation $\left(10 \mathrm{~min}\right.$ at $16,000 \times \mathrm{g}$ and $\left.4{ }^{\circ} \mathrm{C}\right)$ and washed with $500 \mu \mathrm{L}$ ethanol (70\%). Wizard SV Columns (Promega, Germany) were placed into collection tubes and loaded with the samples, followed by a centrifugation step of $11,000 \times g$ and $4{ }^{\circ} \mathrm{C}$ for $2 \mathrm{~min}$. The columns were washed twice using $700 \mu \mathrm{L}$ 2-propanol (80\%), placed into new tubes and dried for $5 \mathrm{~min}$ at RT. Finally, the DNA was eluted using $50 \mu \mathrm{L}$ of a pre-warmed $\left(70{ }^{\circ} \mathrm{C}\right)$ Tris- $\mathrm{HCl}$ buffer and stored at $-20{ }^{\circ} \mathrm{C}$ until used.

\section{DNA extraction from whole milk}

For the assay validation and standard preparation for quantitative real-time PCR, $300 \mu \mathrm{L}$ of whole milk was spiked with the extracted genomic DNA containing different copy numbers of the $\operatorname{cry} 1 \mathrm{Ab}$ (10 to $10^{6}$ copies). Copy numbers were calculated following the formula: (genomic DNA concentration in pg $\mu \mathrm{L}^{-1} \times 6.0233 \times 10^{23}$ copies $\left.\mathrm{mol}^{-1}\right) /\left(\right.$ haploid maize genome size $(\mathrm{bp}) \times 660 \times 10^{12}$ ) [15] . Therefore, a genome size of $2.5 \mathrm{Mbps}$ for the haploid maize genome [16] was used for the conversion of DNA

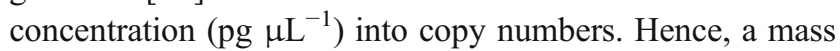
of $2.74 \mathrm{pg}$ of genomic DNA from transgenic maize contained one copy of crylAb DNA.

A previously published guanidinhydrochloride-based extraction protocol [14] was optimized to re-isolate the recombinant DNA from the spiked milk samples. In brief, $860 \mu \mathrm{L}$ extraction buffer, $100 \mu \mathrm{L}$ guanidinhydrochloride solution, and $40 \mu \mathrm{L}$ Proteinase $\mathrm{K}\left(20 \mathrm{mg} \mathrm{mL}^{-1}\right)$ were added to the spiked milk samples. The mixture was incubated at $60{ }^{\circ} \mathrm{C}$ overnight while shaking and subsequently centrifuged for $10 \mathrm{~min}$ at $12,000 \times \mathrm{g}$. The clear supernatant was transferred into a new $1.5 \mathrm{~mL}$ tube and RNA was digested by RNAse $\mathrm{A}$ exposure $\left(5 \mathrm{~min}\right.$ at $60{ }^{\circ} \mathrm{C}$ while shaking).
Wizard SV Columns were placed into collection tubes and loaded with the samples, followed by a centrifugation step of $10,000 \times g$ and $4{ }^{\circ} \mathrm{C}$ for $2 \mathrm{~min}$. The column was washed twice using $800 \mu \mathrm{L}$ 2-propanol (80\%). Remaining 2-propanol was removed by drying the column for $10 \mathrm{~min}$. Finally, DNA was eluted with $50 \mu \mathrm{L}$ pre-warmed $\left(70{ }^{\circ} \mathrm{C}\right)$ elution buffer and stored at $-20^{\circ} \mathrm{C}$ until analyzed.

For subsequent analysis of milk samples collected from the feeding trial, genomic DNA was extracted from $300 \mu \mathrm{L}$ of raw milk sample. Concentrations of DNA in the extracted samples were determined by photometrical analysis using a Biophotometer (Eppendorf, Germany). The purity of DNA was evaluated by using UV absorption ratios of $260 / 280 \mathrm{~nm}$ and $260 / 230 \mathrm{~nm}$.

\section{Conventional PCR}

Qualitative endpoint PCR was performed using $100 \mathrm{ng}$ of genomic DNA (isolated from crylAb spiked milk) to amplify a 354 bp fragment of glyceraldehyde-3-phosphate dehydrogenase (GAPDH, using forward primer 5'ATCACTGCCACCCAGAAGAC-3', reverse primer 5'CCCAGCATCGAAGGTAGAAG-3') as a positive DNA extraction control for endogenous reference gene and a $206 \mathrm{bp}$ fragment of the crylAb gene [17] to verify the extraction method. The PCR mix consisted of $1 \times$ GoTaq Green Master Mix (Promega, Germany), $0.8 \mu \mathrm{M}$ forward and reverse primers (Metabion, Germany). PCR-grade water was added resulting in a final volume of $25 \mu \mathrm{L}$. Water served as a negative control, while genomic DNA (100 ng) from GM maize served as a positive control for crylAb amplification. The following cycling conditions were used: initial denaturation at $94{ }^{\circ} \mathrm{C}$ for $5 \mathrm{~min}$, denaturation at $94{ }^{\circ} \mathrm{C}$ for $30 \mathrm{~s}$, annealing at $55^{\circ} \mathrm{C}($ GAPDH $)$ or $60^{\circ} \mathrm{C}($ crylAb) for $30 \mathrm{~s}$, extension at $72{ }^{\circ} \mathrm{C}$ for $30 \mathrm{~s}$ and final extension at $72{ }^{\circ} \mathrm{C}$ for $5 \mathrm{~min}$. A total of 35 cycles was completed for $G A P D H$, 40 cycles for crylAb, respectively. The PCR product was separated by gel electrophoresis and visualized by staining with GelRed (Biotium, Hayward, USA).

\section{Quantitative real-time PCR ( $q P C R)$}

Quantification of a $206 \mathrm{bp}$ fragment of the $c r y 1 A b$ in milk was carried out using the LightCycler-system (Roche Diagnostics, Germany) with $1 \mu \mathrm{L}$ DNA template (standard or sample genomic DNA extracted from $300 \mu \mathrm{L}$ milk), $1 \mu \mathrm{L}$ LC FastStart DNA Master SYBR Green I (Roche Diagnostics, Mannheim, Germany), $4 \mathrm{pM}$ of each primer and $3 \mathrm{mM}$ $\mathrm{MgCl}_{2}$ under the following cycling conditions: initial denaturation at $95{ }^{\circ} \mathrm{C}$ for $10 \mathrm{~min}$ to activate the DNA polymerase and to ensure complete denaturation of the DNA samples, denaturation at $95{ }^{\circ} \mathrm{C}$ for $15 \mathrm{~s}$, annealing at $60{ }^{\circ} \mathrm{C}$ for $10 \mathrm{~s}$ and extension for $25 \mathrm{~s}$. A fourth step at $86{ }^{\circ} \mathrm{C}$ was 
added to remove unspecific signals before fluorescence acquisition. The PCR was performed in a reaction volume of $10 \mu \mathrm{L}$ and was composed of 40 cycles. All runs included a negative control consisting of PCR-grade water. Additionally, a melting curve analysis was accomplished to check for correct amplification by melting temperature of the expected product. DNA products were sent for commercial sequencing to verify the specificity of the PCR product (data not shown). Samples were measured in duplicates and analyzed using the standard curve method. A standard curve was created by using $1 \mu \mathrm{L}$ of re-isolated genomic DNA after spiking $300 \mu \mathrm{L}$ of milk samples with different copy numbers of crylAb $\left(10\right.$ to $\left.10^{6}\right)$, following the extraction procedure as described above. Therefore, genomic DNA of MON810 maize containing $10,10^{2}, 10^{3}, 5 \times 10^{3}, 10^{4}, 5 \times 10^{4}, 10^{5}$, $5 \times 10^{5}$ and $10^{6}$ copies of cry $1 A b$ per $300 \mu \mathrm{L}$ of whole milk were re-isolated and dissolved in $50 \mu \mathrm{L}$ elution buffer. Further, $1 \mu \mathrm{L}$ of each standard concentration was used to generate the standard curve.

Data obtained by real-time PCR was analyzed using the LightCycler-system software (Roche, Germany). Data expression levels were recorded as the cycle threshold (CT) value, which was derived using the Second Derivative Maximum Method, identifying the CT of a sample as the cycle number where the sample's fluorescence is detected above the background and the amplification is in the exponential phase.

The dynamic range and the PCR efficiency were determined by plotting the CT values against the log of the estimated DNA copy number of the calibrators to generate a standard curve. The slope of the standard curve was used for the amplification efficiency calculation using the following formula: $\left[\left(10^{-1 / \text {-slope }}\right)-1\right] \times 100$.

\section{Assay validation}

To specify the efficiency of the optimized extraction method, the recovery rate was determined by re-isolation and quantification of cryl $\mathrm{Ab}$ in milk samples spiked with three different copy numbers $(5,000,50,000$ and 500,000 copies; six replicates each). Furthermore, inter- and intra-assay coefficients of variation $(\mathrm{CV})$ were verified by analysis of three standard samples within the standard curve.

Protein analysis

\section{Reagents}

All the reagents were of analytical grade and supplied by Merck (Darmstadt, Germany) unless specified otherwise. HPLC-purified trypsin-activated Cry1Ab protein for standard preparation was generously provided by Dr. William J. Moar, Auburn University, USA.
Immunoaffinity purified $\mathrm{Cry} 1 \mathrm{Ab}$ protein specific polyclonal antibody was raised in rabbits and labeled with biotin as described in detail elsewhere [18].

Antibody coating buffer (CB) was $50 \mathrm{mM}$ sodium carbonate/bicarbonate buffer $\mathrm{pH}$ 9.6. Assay buffer (PBST) was phosphate-buffered saline (PBS; $8 \mathrm{mM}$ sodium phosphate, $137 \mathrm{mM} \mathrm{NaCl}, 2.7 \mathrm{mM} \mathrm{KCl}, 1.5 \mathrm{mM}$ potassium phosphate $\mathrm{pH}$ 7.4) containing $0.1 \%$ Tween 20 .

Matrix-matched calibrators $\left(0.1 \mathrm{ng} \mathrm{mL}^{-1}\right.$ to $\left.25 \mathrm{ng} \mathrm{mL}^{-1}\right)$ and controls $\left(0.2,2.0\right.$ and $\left.8.5 \mathrm{ng} \mathrm{mL}^{-1}\right)$ were prepared by fortifying Cry $1 \mathrm{Ab}$ protein in analyte free pooled tank skim milk collected from cows fed rations containing nontransgenic maize.

\section{ELISA procedure}

The assay was performed in 96-well microtiter plates (Maxisorp $^{\mathrm{TM}}$, Nunc, Denmark) coated with the immunoaffinity purified anti-Cryl $\mathrm{Ab}$ protein rabbit polyclonal antibody (capture antibody) at a concentration of $0.02 \mu \mathrm{g}$ well $^{-1}$ in $100 \mu \mathrm{L}$ coating buffer. Then, the plates were incubated overnight at $4{ }^{\circ} \mathrm{C}$ under gentle shaking. After $12 \mathrm{~h}$, the contents of the coated plates were decanted and remaining unbound active sites on each well were blocked by incubating $300 \mu \mathrm{L}$ of $1 \%$ bovine serum albumin (BSA; SERVA, Heidelberg, Germany) in PBST well ${ }^{-1}$ for $1 \mathrm{~h}$ at RT while shaking. After decantation of the blocking buffer, the capture antibody coated and blocked plates were stored frozen at $-20{ }^{\circ} \mathrm{C}$ until used. At the time of assay, frozen plates were thawed to RT and washed twice with assay buffer using a 96-well microplate washer (SLT Lab Instruments, Tecan, Germany). Aliquots of $40 \mu \mathrm{L}$ matrix-matched calibrators $\left(0.1 \mathrm{ng} \mathrm{mL}^{-1}\right.$ to $\left.25 \mathrm{ng} \mathrm{mL}^{-1}\right)$, controls $(0.2,2.0$ and $\left.8.5 \mathrm{ng} \mathrm{mL}^{-1}\right)$ and unknown skim milk samples were added to respective wells of microtiter plate (in duplicates) followed by the addition of $60 \mu \mathrm{L}$ assay buffer. Plates were incubated for $3 \mathrm{~h}$ at RT while shaking, and washed four times with assay buffer. Then, $100 \mu \mathrm{L}$ biotinylated detection antibody (10 $\mathrm{ng} \mathrm{mL}^{-1}$ diluted in assay buffer) was added to each well, and incubated at RT for $1 \mathrm{~h}$ on a plate shaker. After four washing steps with assay buffer, streptavidinhorseradish peroxidase enzyme conjugate (Roche Diagnostics, Mannheim, Germany; $100 \mu \mathrm{L}$, diluted 1:15,000 times in assay buffer) was added to each well and incubated for $15 \mathrm{~min}$ at room temperature. After four washes, $150 \mu \mathrm{L}$ 3,3',5,5'-tetramethylbenzidine (TMB; Sigma, Germany) enzyme substrate solution was added to each well and plates were incubated for $40 \mathrm{~min}$ at room temperature in dark. Thereafter, the enzymatic reaction was stopped by addition of $2 \mathrm{M}$ sulfuric acid $\left(50 \mu \mathrm{L}\right.$ well $\left.{ }^{-1}\right)$ and the absorbance was then read at $450 \mathrm{~nm}$ in a microplate reader (Sunrise, Tecan, Germany). The calibration curve for Cry1 Ab protein was constructed using online Magellan V6.1 software (Tecan, 
Austria) and the concentration of Cryl $\mathrm{Ab}$ protein in unknown samples was determined by interpolation. All data are presented as ng of Cryl $\mathrm{Ab}$ protein $\mathrm{mL}^{-1}$ milk.

\section{Optimization of ELISA}

Several parameters of assay development, including the optimal choice of assay buffer and the specificity of immunoaffinity purified polyclonal Cry $1 \mathrm{Ab}$ protein antibody, were previously optimized [18]. However, the basic sandwich enzyme immunoassay protocol is used with variation in a series of assays to select the optimal concentrations of the anti-Cry1 $\mathrm{Ab}$ capture and biotin-labeled detection antibodies, and to choose an appropriate sample volume of skim milk for the assay. A sensitive matrix-matched calibration curve was generated to reduce the biasness in analysis results due to the matrix interference.

\section{Assay validation}

The assay was validated according to the criteria specified in the adopted European Commission Decision 2002/657/ EC [19] for the performance and validation of screening and confirmatory analytical methods.

Decision limit $(C C \alpha)$ and detection capability $(C C \beta)$ ELISA validation was carried out using 54 different milk samples (blanks), known to be free of Cryl Ab protein, collected from cows fed on non-transgenic ration reared at three different farms. The samples were analyzed using a sandwich ELISA as described above to demonstrate the range of blank matrix effects and to determine $\mathrm{CC} \alpha$ and $\mathrm{CC} \beta . \mathrm{CC} \alpha$ is equal to the average background noise plus three times the signal to noise level recorded for the Cry1 $\mathrm{Ab}$ protein in the blanks. $\mathrm{CC} \beta$ was calculated by using the equation $\mathrm{CC} \beta=\mathrm{CC} \alpha+1.64 \times \mathrm{SD}_{\mathrm{S}} . \mathrm{SD}_{\mathrm{S}}$ is the standard deviation obtained for above 54 blanks fortified at the spike concentration level of CC $\alpha$. Calculation for $\alpha$ - and $\beta$ error were carried out from the Cry $1 \mathrm{Ab}$ protein background noise level in 54 blanks and fortifying the same samples at concentration level of $\mathrm{CC} \beta$ value. $\alpha$-error is the percentage of blank values exceeding the $\mathrm{CC} \alpha$ value. $\beta$-error is represented by the percentage of blank samples showing signals below the $\mathrm{CC} \alpha$ value when fortified at the concentration level of $\mathrm{CC} \beta$.

Recovery and precision Recovery and precision were determined in accordance with Commission Decision 2002/657/ EC by spiking blanks (pooled tank milk) with Cry1 Ab protein. Recovery was calculated for 6 aliquots of blank skim milk per spike concentration level for five different concentration levels $\left(0.6,0.8,1,10\right.$, and $\left.20 \mathrm{ng} \mathrm{mL}^{-1}\right)$. Precision was expressed by inter- and intra-assay $\mathrm{CV}$ and calculated from the analysis of blank skim milk aliquots fortified with Cry1 Ab protein at three (controls) different concentration levels of $0.2,2.0$, and $8.5 \mathrm{ng} \mathrm{mL}^{-1}$ (three determinants per assay) in 11 assays performed on different days.

Application of validated methods in milk sample analysis of feeding trial

Optimized and validated qPCR and ELISA methods were used for the analysis of milk samples collected from the feeding study to monitor the suspicious presence of recombinant DNA and Cry1 Ab protein in milk.

\section{Results and discussion}

\section{Quantification of recombinant DNA}

Genomic DNA from maize (event MON810) was extracted containing the $c r y l A b$ gene in order to spike whole milk samples with different copy numbers of this gene. Genomic DNA extraction from maize kernels resulted in high concentrations up to $900 \mathrm{ng} \mu \mathrm{L}^{-1}$ with a high DNA quality indicated by $260 / 280 \mathrm{~nm}$ ratio values of $1.6-1.9$.

Whole milk was spiked with predefined copy numbers of cry $1 \mathrm{Ab}$ ranging from 10 to $10^{6}$ copies to assess an assay validation. Photometrical analysis of the isolated milk samples revealed genomic DNA concentrations ranging

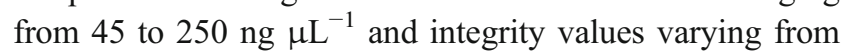
0.9 to 1.6 . The specificity and sensitivity of the primer pair for the amplification of a 206-bp fragment of crylAb DNA from the extracted genomic DNA template from spiked milk sample (containing 10 to $10^{6}$ copies) was tested in conventional PCR along with a negative control (unspiked milk) and a positive control (maize genomic DNA). Specific amplicons (206 bp) were reproducible seen with the genomic DNA extracted from spiked milk containing $\geq 10^{3}$ copies of $c r y l A b$ and positive control (Fig. 1) Absence of the non-specific product and amplicon sequence analysis (data not shown) ensured the specificity of PCR in sample matrix (milk). To ensure the accuracy of genomic DNA extraction from milk, each extracted sample was further tested for the amplification of a 354-bp GAPDH fragment (extraction positive control). Amplification of a bovine GAPDH fragment (354 bp) by means of conventional PCR confirmed the successful DNA extraction from bovine milk (data not shown).

qPCR

Based on qPCR, 100 copies of crylAb per $\mu \mathrm{L}$ were reproducibly detectable by amplification of a 206-bp fragment. Hence, the limit of quantification was set 100 


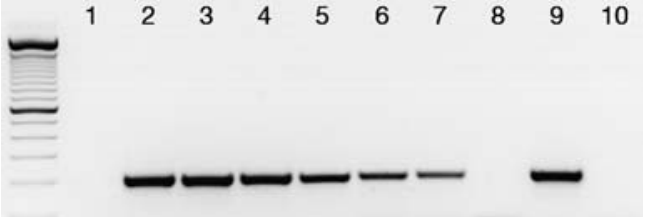

Fig. 1 Specific amplification of a 206-bp fragment of $c r y l A b$ in spiked milk samples (10 to $10^{6}$ copies) by means of conventional PCR. 10 and $10^{2}$ copies of crylAb per $300 \mu \mathrm{L}$ milk were not reproducibly detectable, therefore, the results are not shown in this figure. Lane 1 Non-spiked milk sample, lane 2 milk sample spiked with $10^{6}$ copies of $c r y l A b$, lane 3 milk sample spiked with $5 \times 10^{5}$ copies of $c r y l A b$, lane 4 milk sample spiked with $10^{5}$ copies of cry $1 \mathrm{Ab}$, lane 5 milk sample spiked with $5 \times 10^{4}$ copies of cryl $\mathrm{Ab}$, lane 6 milk sample spiked with $10^{4}$ copies of crylAb, lane 7 milk sample spiked with $5 \times 10^{3}$ copies of $c r y 1 A b$; lane 8 : milk sample spiked with $10^{3}$ copies of $c r y l A b$, lane 9: positive control (genomic DNA extracted from GM maize), lane 10 negative control (water)

copies $/ \mu \mathrm{L}$ genomic DNA. The qPCR was able to detect recombinant DNA concentrations in a dynamic range of $10^{2}$ to $10^{5}$ copies $/ \mu \mathrm{L}$ with an average amplification efficiency of $98 \%$ and an average $R^{2}$ coefficient of 0.98 (Fig. 2). The values of the amplification efficiency and the values of the $R^{2}$ coefficient were within the range of the Minimum Performance Requirements for Analytical Methods of GMO Testing published by the European Network of GMO Laboratories (ENGL).

A melting curve analysis of different standard concentrations $\left(10^{2}\right.$ to $10^{5}$ copies of $\left.c r y 1 A b\right)$ showed a specific amplification by melting temperature $(\mathrm{Tm}) 89{ }^{\circ} \mathrm{C}$ of the specific product (Fig. 3). The specificity of our qPCR assay was further ensured by subsequent amplicon sequence analysis (data not shown). A mean recovery rate of $84.9 \%$ $(n=3$, six replicates each), an intra-assay CV of $0.15(n=9)$ and an inter-assay $\mathrm{CV}$ of $0.78(n=9$, three replicates each)

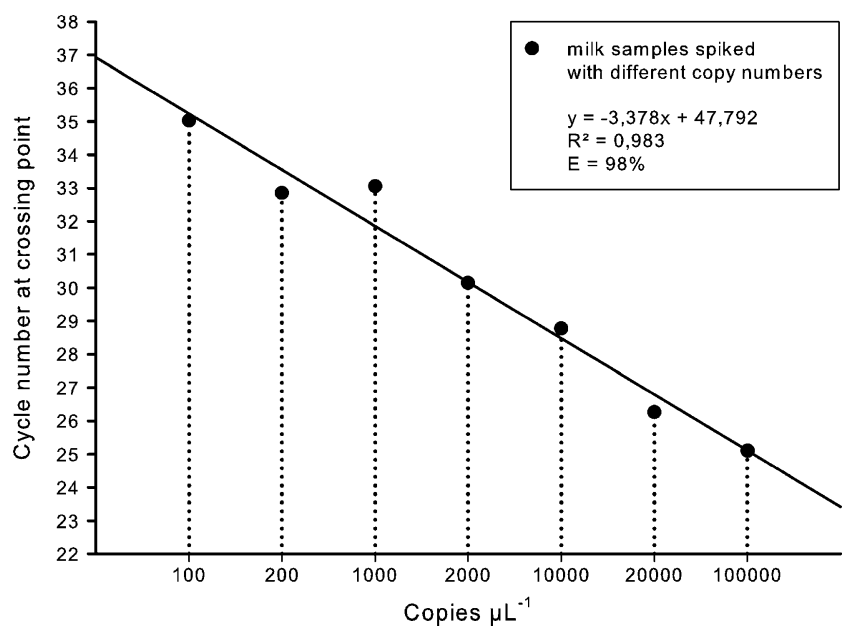

Fig. 2 An exemplary standard curve of milk samples spiked with different copy numbers of $c r y l A b$ as used in the qPCR. The standard curve shows the linearity between 100 and 100,000 copies $\mu \mathrm{L}^{-1}$

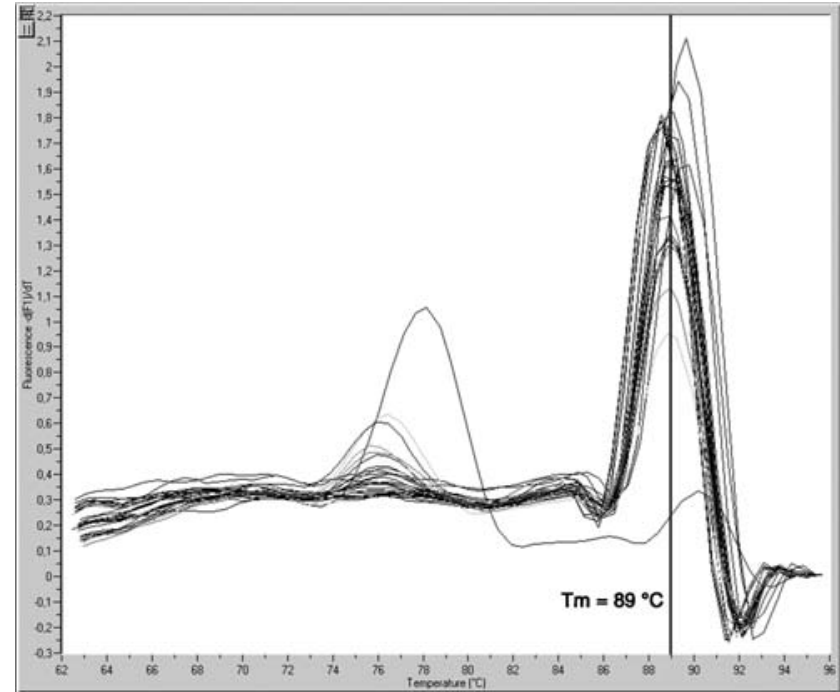

Fig. 3 A melting curve analysis of different standard concentrations $\left(10^{2}\right.$ to $10^{5}$ copies of $\left.c r y l A b\right)$ showing a specific amplification by melting temperature $(\mathrm{Tm}) 89{ }^{\circ} \mathrm{C}$ of the specific product (a $206 \mathrm{bp}$ fragment of cryl $\mathrm{Ab}$ )

illustrate the suitability of the extraction and quantification procedure for novel DNA in whole milk (Table 2).

Quantification of the CrylAb protein

\section{Optimization of assay}

The optimal concentrations of the anti-Cry $1 \mathrm{Ab}$ capture and biotin-labeled detection antibodies were determined by a twodimensional checkerboard titer test against the fixed concentration of $1 \mathrm{ng}$ per well Cry $1 \mathrm{Ab}$ protein. The titer test was performed on a 96-well microtiter plate by coating wells with a dilution range of $0.008 \mu \mathrm{g}$ to $0.1 \mu \mathrm{g}$ per well of capture antibody and measuring the absorbance against the fixed concentration of $1 \mathrm{ng}$ well ${ }^{-1} \mathrm{Cry} 1 \mathrm{Ab}$ protein using a dilution range of 0.063 to $2 \mathrm{ng} / \mathrm{well}$ of detection antibody. The ELISA values (absorbance at $450 \mathrm{~nm}$ ) obtained after substrate reaction were used for choosing the optimal concentration of antibody pairs. The concentrations of the antibody pair was chosen, when the maximum absorbance values $\left(A_{\max }\right)$ were around 1.0 to 1.5 and the respective values of negative antiserum (blanks) was lower than 0.1. As a result, the optimal concentrations of antigen capture and biotin-labeled detection antibodies were $0.2 \mu \mathrm{g} \mathrm{mL}^{-1}$ and $10 \mathrm{ng} \mathrm{mL}$, respectively. The optimized antibody concentrations for pairing $\mathrm{Cry} 1 \mathrm{Ab}$ protein were used in subsequent assays.

\section{Matrix interference and assay sensitivity}

One of the common challenges of immunoassays is the matrix interference. This can be reduced by either sample dilution with buffers or by using a matrix-matched calibra- 
Table 2 Analytical precision for real-time quantitative PCR and ELISA in spiked bovine milk

\begin{tabular}{|c|c|c|c|c|c|c|c|c|}
\hline \multirow[t]{3}{*}{ Coefficient of variation $(\mathrm{CV})^{\mathrm{a}}$} & \multicolumn{4}{|c|}{ Real-time qPCR (DNA) } & \multicolumn{4}{|c|}{ ELISA (Protein) } \\
\hline & \multicolumn{3}{|c|}{ Spiked crylAb controls } & \multirow{2}{*}{$\begin{array}{l}\text { Mean } \\
\mathrm{CV}\end{array}$} & \multicolumn{3}{|c|}{ Spiked Cry $1 \mathrm{Ab}$ controls } & \multirow{2}{*}{$\begin{array}{l}\text { Mean } \\
\mathrm{CV}\end{array}$} \\
\hline & $\begin{array}{l}\mathrm{C} 1 \\
10^{4} \text { copies } \mu \mathrm{L}^{-1}\end{array}$ & $\begin{array}{l}\mathrm{C} 2 \\
10^{3} \text { copies } \mu \mathrm{L}^{-1}\end{array}$ & $\begin{array}{l}\mathrm{C} 3 \\
10^{2} \text { copies } \mu \mathrm{L}^{-1}\end{array}$ & & $\begin{array}{l}\mathrm{C} 1 \\
0.2 \mathrm{ng} \mathrm{mL}\end{array}$ & $\begin{array}{l}\mathrm{C} 2 \\
\text { 2ng mL }\end{array}$ & $\begin{array}{l}\mathrm{C} 3 \\
8.5 \mathrm{ng} \mathrm{mL}\end{array}$ & \\
\hline Intra-assay (\%) & 0.03 & 0.07 & 0.36 & 0.15 & 12.3 & 6.7 & 8.2 & 9.1 \\
\hline Inter-assay (\%) & 0.15 & 0.08 & 2.11 & 0.78 & 13.7 & 7.4 & 8.0 & 9.7 \\
\hline
\end{tabular}

Milk samples collected from cows fed rations containing non-transgenic maize

${ }^{a}$ Coefficients of variation at different spike concentrations of crylAb DNA and Cry1 Ab protein (three determinants per assay) in total 11 independent assays.

tion curve. Here, we have studied the influence of the matrix (analyte free tank skim milk) volume on the assay sensitivity by using Cry $1 \mathrm{Ab}$ protein calibration curves in assay buffer, compared with the addition of different volumes of skim milk $(10,20$, and $40 \mu \mathrm{L})$. The results indicated that the addition of analyte free skim milk has inhibited the $A_{\max }$ and affected the sensitivity of the calibration curve. However, no change was recorded in the absorbance values $\left(A_{\max }\right)$ with the increased sample size from 10 to $40 \mu \mathrm{L}$ per well. As a result, a matrix-matched calibration curve using $40 \mu \mathrm{L}$ sample size (skim milk volume) was used in subsequent assays to nullify the biasness in analysis due to probable matrix interferences (Fig. 4).

A typical matrix-matched $\mathrm{Cry} 1 \mathrm{Ab}$ protein calibration curve using optimized ELISA conditions is shown in Fig. 4. The developed sandwich assay allowed the determination of Cry $1 \mathrm{Ab}$ protein over the dynamic range $(<20 \% \mathrm{CV}$ between the replicates of calibrators) from 0.1 to $25 \mathrm{ng} \mathrm{mL}^{-1}$ with an analytical limit of $0.1 \mathrm{ng} \mathrm{mL}^{-1}$.

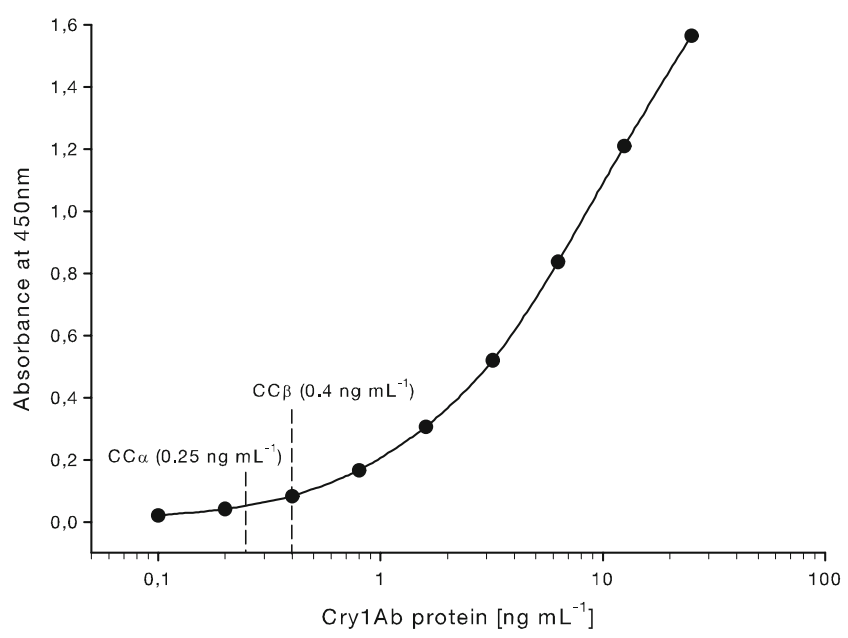

Fig. 4 A typical matrix-matched calibration curve for Cry1Ab protein in bovine skim milk

\section{Milk samples and assay validation}

Decision limits (CC $\alpha)$ and detection capability (CC $\beta)$ Analysis of 54 blank skim milk samples by ELISA showed the background noise for $\mathrm{Cry} 1 \mathrm{Ab}$ protein ranging from $0.1-0.32 \mathrm{ng} \mathrm{mL} L^{-1}$ (mean $0.11 \mathrm{ng} \mathrm{mL}{ }^{-1}$; Fig. 5). The decision limit $(\mathrm{CC} \alpha)$ calculated from the mean background noise $\left(0.11 \mathrm{ng} \mathrm{mL}{ }^{-1}\right)$ plus three times signal to noise level (SD; $0.046 \mathrm{ng} \mathrm{mL}^{-1}$ ) was $0.25 \mathrm{ng} \mathrm{mL}^{-1}$. When same 54 blanks were fortified with Cry1 Ab protein at the concentration level of $\mathrm{CC} \alpha\left(0.25 \mathrm{ng} \mathrm{mL}^{-1}\right)$, the values ranged from $0.17-0.73 \mathrm{ng} \mathrm{mL}^{-1}$ (mean; $0.22 \mathrm{ng} \mathrm{mL}^{-1}$; $\mathrm{SD}_{\mathrm{S}} 0.08 \mathrm{ng} \mathrm{mL}^{-1}$; Fig. 5). The detection capability (CC $\beta)$ calculated from the equation $\mathrm{CC} \beta=\mathrm{CC} \alpha+1.64 \times \mathrm{SD}_{\mathrm{S}}$ was $0.4 \mathrm{ng} \mathrm{mL} L^{-1}$. The observed Cry $1 \mathrm{Ab}$ protein values for the blanks fortified at concentration level of $\mathrm{CC} \beta\left(0.4 \mathrm{ng} \mathrm{mL}{ }^{-1}\right)$ ranged from 0.28-0.71 ng mL ${ }^{-1}$ (mean $0.42 \mathrm{ng} \mathrm{mL}^{-1}$ ) (Fig. 5). Detection capability $\left(0.4 \mathrm{ng} \mathrm{mL}^{-1}\right)$ and threshold value of $0.28 \mathrm{ng} \mathrm{mL}^{-1}$ (the lowest observed $0.4 \mathrm{ng} \mathrm{mL}^{-1}$ fortified sample) laid the basis for selection of the samples for confirmatory analysis. Therefore, the samples with a concentration level at and above $0.28 \mathrm{ng} \mathrm{mL} \mathrm{mus}^{-1}$ me analyzed by any other confirmatory method to draw a final conclusion. The assay $\beta$-error is zero since no false negative (false compliant) results were obtained for $0.4 \mathrm{ng} \mathrm{mL}^{-1}$ fortified blank skim milk samples. This satisfies EU Commission Decision 2002/ 657/EC [19] which states that screening assays must "have a false compliant rate of $<5 \%$ ( $\beta$-error) at the level of interest". Similarly, the $\alpha$-error (false non-compliant) is $<5 \%$ as one blank value exceeded the $\mathrm{CC} \alpha\left(0.25 \mathrm{ng} \mathrm{mL}^{-1}\right)$ value.

Recovery and precision The analytical performance of the developed enzyme immunoassay was assessed by spiking matrix samples (whole tank milk) with the Cry1 Ab protein. The immunoassay performed well when it was applied to spiked whole milk samples and recoveries in skim milk ranged from 88 to $104 \%$ (mean value of $97 \%$; Table 3). The $\mathrm{Cry} 1 \mathrm{Ab}$ protein fortified skim milk blanks at spike 


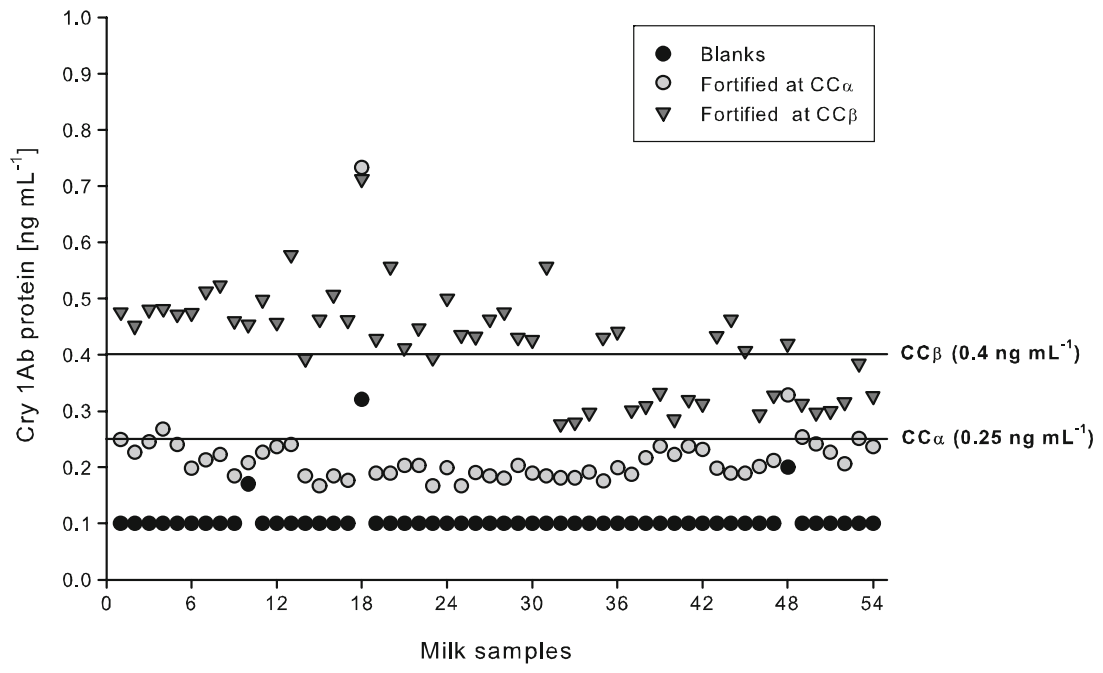

Fig. 5 Determination of decision limit $(\mathrm{CC} \alpha)$ and detection capability $(\mathrm{CC} \beta)$ and $\alpha$ - and $\beta$-errors for the Cry $1 \mathrm{Ab}$ protein ELISA in bovine skim milk. $\mathrm{CC} \alpha$ calculated as mean background noise plus three times $\mathrm{S} / \mathrm{N}$ ratio from the 54 blanks (filled circle skim milk collected from 54 cows fed non-transgenic ration). Detection capability was calculated from the

concentrations of $0.2,2.0$, and $8.5 \mathrm{ng} \mathrm{mL}^{-1}$ (three determinants per assay) in 11 independent assays showed a good assay precision, with intra- and inter-assay CVs of 9.1 and $9.7 \%$, respectively (Table 2 ).

The analytical performance of the assay indicates that it can be used for monitoring concentration levels of CrylAb protein in bovine milk.

\section{Surveillance of recombinant DNA and Cry1Ab protein in milk of cows fed transgenic maize (MON810)}

In total, 90 milk samples collected from eight transgenic and seven non-transgenic ration-fed cows during 6 months feeding trial were analyzed for the suspicious presence or absence of the $c r y 1 A b$ and Cryl Ab protein using developed
Cry1 Ab protein fortified blanks (empty circle $n=54$ ) at concentration of $0.25 \mathrm{ng} \mathrm{mL}^{-1}(\mathrm{CC} \alpha)$. Percentage of blanks showing the signals above the $\mathrm{CC} \alpha$ value $\left(0.25 \mathrm{ng} \mathrm{mL}^{-1}\right)$ indicated the $<5 \% \alpha$-error. Zero $\beta$-error was indicated by the spiked blanks (inverted filled triangle) fortified at $\mathrm{CC} \beta$ value of $0.4 \mathrm{ng} \mathrm{mL}^{-1}$

qPCR and ELISA, respectively. In both feeding groups, no milk sample was found suspicious for the presence of novel DNA and protein (Fig. 6) at assay detection limits. These results are in accordance with the few previous findings that also reported the absence of recombinant DNA and protein in milk [10, 13, 20-22]. Contrary to this, Agodi et al. [9] detected small fragments of recombinant DNA in analyzed milk samples from the Italian market, which they suspected was due to feed and fecal contamination during milking of cows offered GM diets. Degradation of the intact transgenic DNA and protein during feed processing, storage, and ruminal plus intestinal digestion might be the reasons for the absence of these recombinant fragments in milk. Previous studies on GM maize [23-25] reported that the degradation of plant DNA starts directly after harvest due to bacterial activity and is also greatly influenced by feed

Table 3 Recoveries achieved for crylAb DNA and Cry1Ab protein determination in spiked bovine milk

\begin{tabular}{|c|c|c|c|c|c|}
\hline \multicolumn{3}{|l|}{ crylAb DNA } & \multicolumn{3}{|l|}{ Cry $1 \mathrm{Ab}$ protein } \\
\hline $\begin{array}{l}\text { Amount added } \\
\text { [copies } 300 \mu \mathrm{L}^{-1} \text { ] }\end{array}$ & Amount measured & Recovery [\%] & $\begin{array}{l}\text { Amount added } \\
{\left[\mathrm{ng} \mathrm{mL}^{-1} \text { milk] }\right.}\end{array}$ & Amount measured & Recovery $[\%]$ \\
\hline $5 \times 10^{5}$ & $4.66 \times 10^{5} \pm 1 \times 10^{5}$ & 93.1 & 0.6 & $0.625 \pm 0.026$ & 104.1 \\
\hline $5 \times 10^{4}$ & $5.47 \times 10^{4} \pm 1.84 \times 10^{4}$ & 109.3 & 0.8 & $0.784 \pm 0.072$ & 97.9 \\
\hline \multirow[t]{3}{*}{$5 \times 10^{3}$} & $2.61 \times 10^{3} \pm 1.1 \times 10^{3}$ & 52.2 & 1.0 & $0.879 \pm 0.041$ & 87.9 \\
\hline & & & 10 & $9.333 \pm 0.617$ & 93.3 \\
\hline & & & 20 & $20.230 \pm 1.547$ & 101.2 \\
\hline Mean recovery [\%] & & 84.9 & Mean recovery [\%] & & 96.9 \\
\hline
\end{tabular}

Milk samples collected from non-GM ration-fed cows.

Mean value \pm standard deviation (six replicates) 


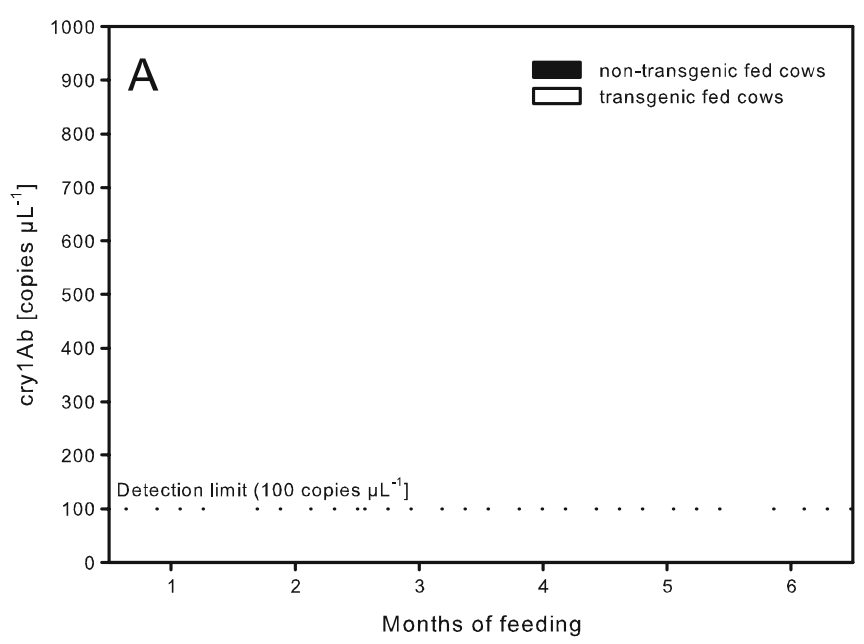

Fig. 6 Background signals for crylAb DNA and Cry1 Ab protein in milk of cows fed transgenic $(n=8)$ and non-transgenic ration $(n=7)$. No sample found suspicious for the presence of crylAb DNA (a) and

treatment. After feed intake, both the DNA and protein are further degraded within the bovine gastrointestinal tract (GIT) $[26,27]$. So, it is very unlikely that intact DNA passes the GIT and is available for absorption via the Peyers' Patches [28]; though small fragments of nontransgenic plant DNA were found in mouse cells and tissues that are part of the immune system [29]. Also, small fragments of multicopy plant chloroplast DNA were detected in some animal tissues (blood, tissue, milk) [12, $22,30,31]$, but so far, no study revealed a transfer of novel DNA from the blood circle to the mammary gland in any species. Authors suggested to further investigate the mechanisms of molecule transport across the epithelial layer of the GIT into blood stream.

Another reason for the absence of Cry $1 \mathrm{Ab}$ protein in milk could be the lack of the absorption mechanisms involved in the transfer of this protein from the gut into blood stream to enter the mammary gland for final secretion in milk. This could be further supported by the findings reporting the lack of Cryl $\mathrm{Ab}$ protein specific receptors on bovine intestinal epithelium [32, 33]; though so far, no single-copy genes (including transgenes) and Cry $1 \mathrm{Ab}$ protein were detected in milk of cows fed GM ration. However, to ensure the potential absence or presence of transgenic DNA and protein in milk of cows, long-term GM-feeding effects need to be further evaluated. Therefore, the validated methods for the quantification of GM DNA and $\mathrm{Cry} 1 \mathrm{Ab}$ protein will further facilitate the reliable analysis of milk samples.

To the best of our knowledge, these are the first available methods for a specific detection of $c r y 1 A b$ DNA and the Cry $1 \mathrm{Ab}$ protein in milk of cows fed transgenic maize fulfilling all the validation criteria as prescribed in the guidelines of EU-Decision 2002/657/EC. Further, these

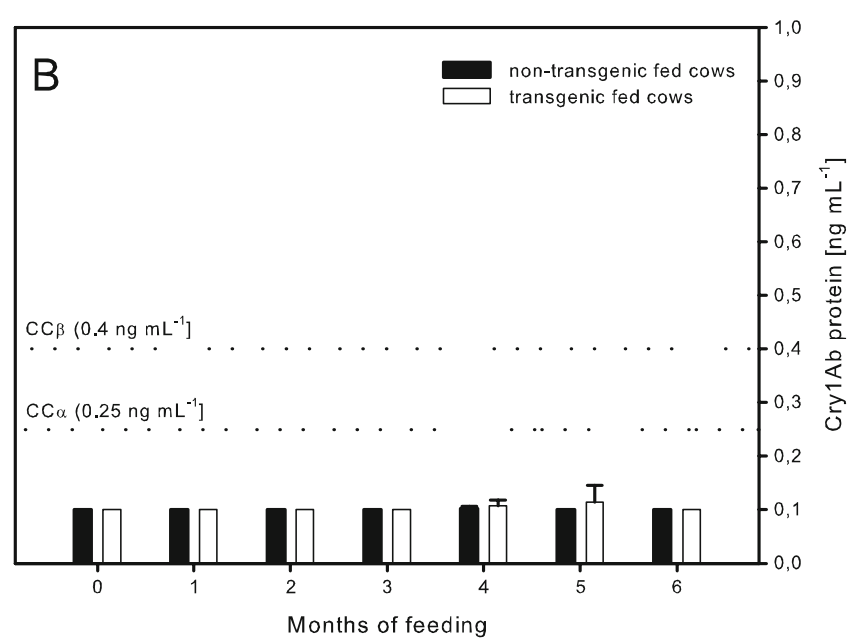

Cry1Ab protein (b) in milk. All the ELISA values were below the decision limit $\left(0.25 \mathrm{ng} \mathrm{mL}^{-1}\right)$ and detection capability $\left(0.4 \mathrm{ng} \mathrm{mL}^{-1}\right)$. The data is presented as mean $( \pm \mathrm{SD})$ values

methods can be used for reliable monitoring of milk samples for unwanted suspicious presence of $c r y 1 \mathrm{Ab}$ DNA and Cry $1 \mathrm{Ab}$ protein to address the authenticity concerns of respective consumers.

\section{Conclusions}

Highly specific and sensitive quantitative real-time PCR and sandwich ELISA have been developed for the $c r y l A b$ DNA and Cry1 $\mathrm{Ab}$ protein determination at low levels of crylAb (100 copies) and Cry1 Ab protein ( $\mathrm{CC} \beta \quad 0.4 \mathrm{ng}$ $\mathrm{mL}^{-1}$ ) in bovine milk, respectively. The developed assays satisfy the performance and validation criteria laid down by Commission Decision 2002/657/EC. Both the methods performed well when applied to spiked milk samples and mean recoveries in milk were 84.9 and $96.9 \%$ for $\mathrm{cry} 1 \mathrm{Ab}$ and $\mathrm{Cry} 1 \mathrm{Ab}$ protein, respectively. Based on the good recovery and assay performance, the assays found suitable for recording a potential transfer of novel DNA and Cry1 $\mathrm{Ab}$ protein into milk of cows fed a transgenic ration supplemented with MON810. When applied for the surveillance of novel DNA and immuno detective protein fragments from Bt-maize in milk of cows fed transgenic ration for a 6-month feeding study, no milk sample was suspicious for the presence of recombinant DNA and the Cryl Ab protein.

These validated methods could further be used for the analysis of milk samples collected from the cows fed continuously for a long-term on transgenic ration to monitor the unwanted suspicious potential existence of recombinant DNA and Cry1 Ab protein in the milk, which could answer the questions raised on the long-term GM feeding and food authenticity concerns of respective consumers. 
Acknowledgments This study was funded by the Bavarian State Ministry of Nutrition, Agriculture and Forestry. The authors thank E. Englberger and T. Janke for their assistance. The staff at the Physiology Weihenstephan and the Bavarian State Research Center is gratefully acknowledged.

\section{References}

1. Hofte H, Whiteley HR (1989) Microbiol Rev 53:242-255

2. James C (2008) ISAAA Brief No. 37

3. (2003) Official Journal of the European Union

4. Hupfer C, Hotzel H, Sachse K, Engel K-H (1997) Eur Food Res Technol 205:442-445

5. Michelini E, Simoni P, Cevenini L, Mezzanotte L, Roda A (2008) Anal Bioanal Chem 392:355-367

6. Peano C, Samson MC, Palmieri L, Gulli M, Marmiroli N (2004) J Agric Food Chem 52:6962-6968

7. Vaitilingom M, Pijnenburg H, Gendre F, Brignon P (1999) J Agric Food Chem 47:5261-5266

8. Marmiroli N, Maestri E, Gulli M, Malcevschi A, Peano C, Bordoni R, De BG (2008) Anal Bioanal Chem 392:369-384

9. Agodi A, Barchitta M, Grillo A, Sciacca S (2006) Int J Hyg Environ Health 209:81-88

10. Phipps RH, Beever DE, Humphries DJ (2002) Lives Prod Sci 74:269-273

11. Poms RE, Hochsteiner W, Luger K, Glossl J, Foissy H (2003) J Food Prot 66:304-310

12. Einspanier R, Andreas K, Jana K, Karen A, Rita P, Fredi S, Gerhard J, Gerhard F (2001) Eur Food Res Technol V212:129-134

13. Calsamiglia S, Hernandez B, Hartnell GF, Phipps R (2007) J Dairy Sci 90:4718-4723

14. Swiss Food Manual (2004) Eidgenössische Drucksachen- und Materialienzentrale, Bern
15. Mitchell JA, Brooks H, Shiu KB, Brownlie J, Erles K (2009) J Virol Methods 155:136-142

16. Arumuganathan K, Earle ED (1991) Plant Mol Biol Rep 9:208-218

17. Guertler P, Lutz B, Kuehn R, Meyer HHD, Killermann B, Albrecht C (2007) Eur J Wildl Res 54:36-43

18. Paul V, Steinke K, Meyer HH (2008) Anal Chim Acta 607:106-113

19. (2002) Official Journal of the European Communities L221

20. Phipps RH, Jones AK, Tingey AP, Abeyasekera S (2005) J Dairy Sci 88:2870-2878

21. Nemeth A, Wurz A, Artim L, Charlton S, Dana G, Glenn K, Hunst P, Jennings J, Shilito R, Song P (2004) J Agric Food Chem 52:6129-6135

22. Phipps RH, Deaville ER, Maddison BC (2003) J Dairy Sci 86:4070-4078

23. Hupfer C, Hotzel H, Sachse K, Engel K-H (1998) Eur Food Res Technol 206:203-207

24. Hupfer C, Mayer J, Hotzel H, Sachse K, Engel K-H (1999) Eur Food Res Technol 209:301-304

25. Lutz B, Wiedemann S, Albrecht C (2006) Anim Physiol Anim Nutr (Berl) 90:116-123

26. Wiedemann S, Lutz B, Kurtz H, Schwarz FJ, Albrecht C (2006) J Anim Sci 84:135-144

27. Lutz B, Wiedemann S, Einspanier R, Mayer J, Albrecht C (2005) J Agric Food Chem 53:1453-1456

28. Schubbert R, Renz D, Schmitz B, Doerfler W (1997) Proc Natl Acad Sci USA 94:961-966

29. Hohlweg U, Doerfler W (2001) Mol Genet Genomics 265:225233

30. Klotz A, Mayer J, Einspanier R (2002) Eur Food Res Technol 214:271-275

31. Reuter T, Aulrich K (2003) Eur Food Res Technol 216:185-192

32. Shimada N, Miyamoto K, Kanda K, Murata H (2006) Appl Entomol Zool 41:295-301

33. Shimada N, Miyamoto K, Kanda K, Murata H (2006) In Vitro Cell Dev Biol Anim 42:45-49 